\title{
PHYLOGENETIC ANALYSIS OF COTTON SPECIES (DIPLOID GENOMES) USING SINGLE NUCLEOTIDE POLYMORPHISMS (SNPs) MARKERS
}

\author{
Tayyaba Shaheen ${ }^{1,2}$, Yusuf Zafar ${ }^{1}$ and Mehboob-ur-Rahman ${ }^{1 *}$ \\ ${ }^{1}$ Plant Genomics and Molecular Breeding (PGMB) Labs., National Institute of \\ Biotechnology and Genetic Engineering (NIBGE), Faisalabad, Pakistan Atomic Energy Commission, Islamabad, \\ Pakistan; ${ }^{2}$ Department of Bioinformatics and Biotechnology, Government College University, Faisalabad, Pakistan. \\ *Corresponding author's e-mail: mehboob_pbd@yahoo.com
}

\begin{abstract}
Genus cotton has total 50 species, diploid species fall into 8 genomic groups (A-G, and $\mathrm{K}$ ). To the extent of our knowledge, frequency of single nucleotide polymorphisms (SNPs) has not been calculated in genes of multiple genomes of the genus Gossypium. Here we present the frequency of SNPs in the transcribed regions of the multiple genes, and their utility in resolving phylogenies among 11 diploid species representing five of the eight diploid genomes of the genus Gossypium. We explored the expressed sequence tags (ESTs) data set of G. arboreum showing homology with genes encoding for mitochondrial small heat shock protein (MT-sHSP), histone $\mathrm{H}_{2} \mathrm{~B}_{1}$, S-adenosyl methionine synthetase, cytochrome p450, actin-depolymerizing factor 2, C-terminal domain of helicases and histone $\mathrm{H}_{2} \mathrm{~B}_{3}$ for designing primers. The resultant PCR products amplifying partial gene sequences were sequenced. In total, 61 SNPs were detected in cotton genomes which include 53 substitutions and 8 Indels in the total $1920 \mathrm{bp}$ genome length. Phylogenetic analysis using this data revealed grouping of genomes comparable with previous studies. $\mathrm{A}_{1}$ and $\mathrm{A}_{2}$ genomes were most similar (98.0\%) while $\mathrm{D}_{9}$ and Oryza genomes were least similar (31.2\%). Oryza was most distantly related with other genomes. In conclusion SNPs are potent markers to delineate cotton genomes according to their evolutionary positions.
\end{abstract}

Keywords: SNPs, genetic diversity, phylogeny, comparative genomics, Gossypium.

\section{INTRODUCTION}

Single nucleotide polymorphisms (SNPs) are the most abundant source of variations in plant and animal genomes (Chen et al., 1999; Ayeh, 2008; Duran et al., 2009; Bansal et al., 2010; Huang et al., 2012; Huang et al., 2016) which are present in coding as well as non-coding regions of the genomes (Aerts et al., 2002). Their distribution is random, and sometimes associated with morphological traits (Lindblad-Toh et al., 2000; Gamazon et al., 2010). SNPs are useful for characterizing allelic variation, QTL mapping, and implementing marker-assisted selection (MAS). For example, in Arabidopsis, more than one million non-redundant SNPs were identified which can be used in disequilibrium mapping studies (Clark et al., 2007). Similarly, higher plants like barley (Kanazin et al., 2002; Duran et al., 2009), maize (Tenaillon et al., 2001), soybean (Zhu et al., 2003) and sugar beet (Schneider et al., 2001) have been surveyed for discovering SNPs.

Genetic improvement of cotton fiber production and its properties will be enhanced by the availability of rapidly developing genetic resources and tools, including highdensity genetic maps (Rong et al., 2004; Lacape et al., 2005). Very few studies have been reported on identification of SNPs in cotton because of huge genome size coupled with the polyploid nature of cultivated cotton which requires the distinction of allelic SNPs from paralogs. A total of 94 SNPs including 36 single-base changes $(38.3 \%)$ and 58 indels $(61.7 \%)$ were identified in 16 fiber gene fragments of $G$. hirsutum and $G$. barbadense by using a PCR based direct sequencing technique (Lu et al., 2005). In the FIFI gene, regulating the fiber development in G. barbadense, three base substitutions were reported while comparing with the corresponding gene in G. hirsutum (Ahmad et al., 2007). In another study, in six $R 2 R 3-M Y B$ transcription factors influencing trichome length and density, one SNP per 77 bases were reported (An et al., 2008). ESTs are a good source for SNPs detection in different plant species. A total of 10,000 SNPs and indels were reported among the ESTs sequences derived from G. hirsutum and its progenitor's species (Udall et al., 2006).

In the present study, we present the phylogeny analysis of different diploid cotton genomes by comparing the sequences of the conserved coding regions of seven loci, which are least prone to mutations (Koornneef et al., 2004), otherwise are difficult to study with conventional DNA marker system (Semagn et al., 2006) because the SNPs are most effective to find the single base variations in any part of the genome as compared to other conventional markers (Ball et al., 2010). Therefore, a study was conducted to harness SNPs and Indels for studying phylogenetic relationships of cotton genomes and these sequences were also compared with the 
corresponding sequences of the sequenced plant genomes. This study will lead to the conclusion how variations at single nucleotide level depict the phylogenetic backgrounds of genomes and what is their role in pace of evolution of different genes. Results obtained with other DNA markers like RAPD, SSRs, AFLP would be compared with the results obtained with SNPs. The present study would set a stage towards exploring the new horizons to scrutinize cotton genes involved in evolution of vital traits.

\section{MATERIALS AND METHODS}

Plant material: Experimental material consisted of 11 diploid species (Table 1). Leaves of the cotton species were collected from CCRI Multan.

Table 1. Diploid cotton species $(2 n=2 x-26)$ used in the present study.

\begin{tabular}{llll}
\hline Sr\# & Species name & Genome & Distribution \\
\hline 1 & G. arboreum & $\left(\mathrm{A}_{2}\right)$ & Old world \\
2 & G. herbaceum & $\left(\mathrm{A}_{1}\right)$ & Africa \\
3 & G. robinsonii & $\left(\mathrm{C}_{2}\right)$ & Australia \\
4 & G. sturtianum & $\left(\mathrm{C}_{1}\right)$ & Australia \\
5 & G. aridum & $\left(\mathrm{D}_{4}\right)$ & Mexico \\
6 & G. raimondii & $\left(\mathrm{D}_{5}\right)$ & Peru \\
7 & G. gossypoides & $\left(\mathrm{D}_{6}\right)$ & Mexico \\
8 & G. lobatum & $\left(\mathrm{D}_{7}\right)$ & Mexico \\
9 & G. laxum & $\left(\mathrm{D}_{9}\right)$ & Mexico \\
10 & G. stocksii & $\left(\mathrm{E}_{1}\right)$ & Arabian peninsula \\
11 & G. nelsonii & $\left(\mathrm{G}_{3}\right)$. & Australia \\
\hline
\end{tabular}

Isolation of total genomic DNA : DNA was extracted from 10 individual plants of each genotype from all 11 species according to the method used by Iqbal et al. (1997). After RNase treatment the DNA concentration was measured by flouremeter DyNA QuantTM 200. DNA quality was checked by running $25 \mathrm{ng}$ DNA on $0.8 \%$ agarose gel The DNA samples, which were not showing a discrete band, were rejected. The DNA was diluted in double distilled water to a concentration of $15 \mathrm{ng} / \mu \mathrm{l}$ for PCR analysis.

Primer designing: Gene specific primers were designed based on conserved regions of ESTs showing homology with genes encoding for MT-sHSP, Histone $\mathrm{H}_{2} \mathrm{~B}_{1}$, S-adenosyl methionine synthetase, Cytochrome p450, Actindepolymerizing factor 2, C-terminal domain of helicases and Histone $\mathrm{H}_{2} \mathrm{~B}_{3}$. Three ESTs for each gene were retrieved from model sequenced organisms (Arabidopsis, rice) to design primers. Primers were designed to amplify conserved partial gene sequences using primer 3 software on the basis of regions spanning the conserved regions. (Table 2) Polymerase chain reaction (PCR) was performed in a total volume of $20 \mu \mathrm{l}$, using $2.5 \mu \mathrm{l}(15 \mathrm{ng} / \mu \mathrm{l})$ of cotton DNA, $10 \mathrm{x}$ PCR buffer without $\mathrm{MgCl}_{2}$ (10mM Tris- $\left.\mathrm{HCl}, 50 \mathrm{mM} \mathrm{KCl}, \mathrm{PH} 8.3\right), 3 \mathrm{mM}$ $\mathrm{MgCl}_{2}, 0.1 \mathrm{mM}$ each of dATP, dGTP, dCTP and dTTP and 0.5 units of Taq DNA polymerase, $0.15 \mathrm{mM}$ of each primer. Taq DNA polymerase together with 10 x PCR buffer, $\mathrm{MgCl}_{2}$ and dNTPs were from MBI Fermentas. Polymerase chain reaction consisted of initial denaturation of $94^{\circ} \mathrm{C}$ for $5 \mathrm{~min}$ and 35 cycles of $94^{\circ} \mathrm{C}$ for $1 \mathrm{~min}, 50^{\circ} \mathrm{C}$ for $30 \mathrm{sec}, 72^{\circ} \mathrm{C}$ extension for $1 \mathrm{~min}$ and final extension at $72^{\circ} \mathrm{C}$ for $10 \mathrm{~min}$. PCR products were resolved on $1 \%$ agarose gel to check amplification.

Sequencing of PCR product: Sequencing of PCR products was done on ABI automated DNA sequencer. Sequences were edited manually to get single read of whole sequence. Four runs of sequencing for each of the PCR product were done to avoid discrepancies in SNP detection. Those SNPs which were detected in all sequencing results were considered valid. Consensus sequence of each of the product was used for alignment and phylogenetic analysis using DNA star.

Table 2. Homology of ESTs used in study and Primer sequences.

\begin{tabular}{|c|c|c|c|}
\hline EST & Best Blast homology & $\begin{array}{l}\text { Organism showing } \\
\text { best homology }\end{array}$ & Primer sequence \\
\hline \multirow[t]{2}{*}{ CON_005_03587 } & Histone $\mathrm{H} 2 \mathrm{~B}-3$ & Arabidopsis thaliana & 5'GCTTAGCCAATTCACCAGGC 3' $^{\prime}$ \\
\hline & & & 5'GCTCCAAGGTTGGTGAGAAG3' \\
\hline \multirow[t]{2}{*}{ CON_001_09243 } & NADPH-cytochrome $\mathrm{P} 450$ reductase & Pisum sativum & 5'CACCCATTTAACCCTTCTCGC3' \\
\hline & & & 5'TGTATGTGTGTGGTGATGCC3' \\
\hline \multirow[t]{2}{*}{ CON_003_02307 } & C-terminal domain of helicases & A. thaliana & 5'TGGCCTTATCTCCGTCACTC3' \\
\hline & & & 5'GAAGCGAAAGACCCTCGAAG3' \\
\hline \multirow[t]{2}{*}{ CON_002_01213 } & Mitochondrial small heat shock protein & Solanum lycopersicum & 5'CTCТССАТСАСССТАAAG3' \\
\hline & & & 5'GTGGAACAGAACACACTC3' \\
\hline \multirow[t]{2}{*}{ CON_001_10630 } & S-adenosyl methionine synthetase & Populus trichocarpa & 5'CCAATGTGATGAAGCTCC3' \\
\hline & & & 5'GGTGTACCTGAACCATTG3' \\
\hline \multirow[t]{2}{*}{ CON_008_04131 } & Histone $\mathrm{H} 2 \mathrm{~B} 1$ & Medicago truncatula & 5'AGAGAAGAAGCCTAAGGC3' \\
\hline & & & 5'TCACCAGGAAGTACAAGC3' \\
\hline \multirow[t]{2}{*}{ CON_006_03927 } & Actin-depolymerizing factor 2 & Populus trichocarpa & 5'CAACCGAAAGCTATGAGG3' \\
\hline & & & 5'TGTAGGAAGGAAGGAAGC3' \\
\hline
\end{tabular}


Sequences of already sequenced genomes Arabidopsis thaliana, Carica papaya, Vitis vinifera, populus trichocarpa and Oryza sativa were obtained from GenBank for all the seven loci. Maximum similarity of all cotton patial gene sequences sequences was searched with BLAST search tool in NCBI (Blastn).

SNPs detection, similarity matrix and phylogenetic analysis: Seven gene sequences from each of eleven diploid species were used for SNP detection. The Genbank sequences of $A$. thaliana, Carica papaya, Vitis vinifera, populus trichocarpa and Oryza sativa were used as outgroup species. DNASTAR (DNASTAR Inc., Madison, WI, USA) and Clustal v were used for sequence alignment. Phylogenetic analyses were performed using Megalign DNASTAR. Similarity matrix and phylogenetic analysis was performed based on cumulative sequences of all seven partial gene sequences amplified from cotton and retrieved sequences from five sequenced genome.

Chromosomal assignment: Positions of the genes were known on Arabidopsis chromosomes. This information was used following the comparative genomics of Arabidopsis and cotton (Rong et al., 2005) to find their position on cotton chromosomes.

\section{RESULTS}

Comparison with other genomes: Sequences of the genes obtained from cotton (G. arboreum) were compared with reported corresponding gene sequences from other plant species (Table 2). Two sequences have shown maximum similarity with $A$. thaliana, two have shown with populus, while others with Pisum sativum, Medicago truncatula, Solanum lycopersicum and Vitis vinifera (Table 2).

Types and distribution of SNPs within Gossypium diploid genomes: In total 61 SNPs were detected in 1920 bp (Total cumulative sequence length obtained by amplification of partial gene sequences in cotton) (out of these, 53 were substitutions and 8 were Indels. A total of $39(73.5 \%)$ substitutions were transitions and $14(26.5 \%)$ substitutions were transversions. Maximum SNPs (16) were detected in Sadenosyl methionine synthetase proteins gene and minimum (2) in gene encoding for C-terminal domain of helicases (Table 3).

Assignment of the position of genes on Arabidopsis and cotton chromosomes: All genes included in the study are single copy genes. Position of these genes on A. thaliana chromosomes are given in Table 4. Position of these genes on Gossypium chromosomes according to comparative genomics of cotton and Arabidopsis by Rong et al. (2005) were determined (Table 4). Two of the genes were present near central region of chromosomes in Arabidopsis while four were present at distal ends. Mitochondrial small heat shock protein is a mitochondrial gene and position of Ubiquitin extension protein could not be determined.

Similarity matrix: Similarity matrix studies for all partial gene sequences spanning total $1920 \mathrm{bp}$ revealed similarity among genomes ranging from $31.2 \%\left(\mathrm{D}_{6} *\right.$ Oryza) to $98.0 \%$

Table 3. Position and nature of SNPs identified.

\begin{tabular}{|c|c|c|c|c|c|}
\hline EST & $\begin{array}{l}\text { Conserved } \\
\text { region }\end{array}$ & $\begin{array}{l}\text { Amplicons } \\
\text { size }\end{array}$ & $\begin{array}{l}\text { No. of SNPs/ } \\
\text { Indels }\end{array}$ & SNP/ Indel location/ position & $\begin{array}{l}\text { SNPs with A. } \\
\text { thaliana }\end{array}$ \\
\hline $\begin{array}{l}\text { Mitochondrial small } \\
\text { heat shock protein }\end{array}$ & $138-440$ & 300 & 13 & $\begin{array}{l}152 \mathrm{~T} \rightarrow \mathrm{C}, 177 \mathrm{G} \rightarrow \mathrm{A}, 178-\mathrm{G} \\
218 \mathrm{C} \rightarrow \mathrm{A}, 246-\mathrm{C}, 332 \mathrm{~A} \rightarrow \mathrm{C} \\
336 \mathrm{~T} \rightarrow \mathrm{C}, 345 \mathrm{C} \rightarrow \mathrm{T}, 346-\mathrm{T} \\
347-\mathrm{C}, 363 \mathrm{G} \rightarrow \mathrm{A}, 361 \mathrm{~T} \rightarrow \mathrm{C} \\
394 \mathrm{~A} \rightarrow \mathrm{G}\end{array}$ & 101 \\
\hline $\begin{array}{l}\text { S-adenosyl } \\
\text { methionine synthetase }\end{array}$ & $43-300$ & 260 & 16 & $\begin{array}{l}86 \mathrm{~A} \rightarrow \mathrm{C}, 89 \mathrm{G} \rightarrow \mathrm{A}, 101 \mathrm{C} \rightarrow \mathrm{T} \\
109-\mathrm{G}, 125-\mathrm{C}, 130 \mathrm{~A} \rightarrow \mathrm{C} \\
136 \mathrm{~A} \rightarrow \mathrm{C}, 149 \mathrm{~A} \rightarrow \mathrm{C}, 154 \mathrm{C} \rightarrow \mathrm{T} \\
160 \mathrm{C} \rightarrow \mathrm{T}, 186 \mathrm{C} \rightarrow \mathrm{T}, 200 \mathrm{C} \rightarrow \mathrm{G} \\
227 \mathrm{C} \rightarrow \mathrm{A}, 228 \mathrm{~A} \rightarrow \mathrm{C}, 272 \mathrm{~T} \rightarrow \mathrm{C} \\
276 \mathrm{G} \rightarrow \mathrm{T}\end{array}$ & 41 \\
\hline Histone $\mathrm{H} 2 \mathrm{~B} 1$ & $194-460$ & 270 & 9 & $\begin{array}{l}203 \mathrm{G} \rightarrow \mathrm{A}, 230 \mathrm{~A} \rightarrow \mathrm{G}, 231 \mathrm{~A} \rightarrow \mathrm{G} \\
344 \mathrm{~T} \rightarrow \mathrm{C}, 382-\mathrm{C}, 388 \mathrm{G} \rightarrow \mathrm{A} \\
410 \mathrm{C} \rightarrow \mathrm{T}, 425 \mathrm{~T} \rightarrow \mathrm{C}, 458 \mathrm{G} \rightarrow \mathrm{A}\end{array}$ & 50 \\
\hline Cytochrome p450 & $251-500$ & 250 & 5 & $\begin{array}{l}375 \mathrm{C} \rightarrow \mathrm{T}, 376 \mathrm{~A} \rightarrow \mathrm{T}, 426 \mathrm{G} \rightarrow \mathrm{A} \\
422-\mathrm{C}, 494 \mathrm{G} \rightarrow \mathrm{A}\end{array}$ & No similarity \\
\hline $\begin{array}{l}\text { Actin-depolymerizing } \\
\text { factor } 2\end{array}$ & $294-490$ & 300 & 4 & $\begin{array}{l}327 \mathrm{~T} \rightarrow \mathrm{C}, 348 \mathrm{~T} \rightarrow \mathrm{C}, 443 \mathrm{~T} \rightarrow \mathrm{C} \\
469 \mathrm{C} \rightarrow \mathrm{T}\end{array}$ & 103 \\
\hline Histone $\mathrm{H}_{2} \mathrm{~B}_{3}$ & $111-400$ & 300 & 12 & $\begin{array}{l}140 \mathrm{C} \rightarrow \mathrm{T}, 155 \mathrm{C} \rightarrow \mathrm{T}, 175 \mathrm{~A} \rightarrow \mathrm{T} \\
187 \mathrm{~A} \rightarrow \mathrm{C}, 189 \mathrm{~T} \rightarrow \mathrm{C}, 272 \mathrm{~T} \rightarrow \mathrm{C} \\
290 \mathrm{~T} \rightarrow \mathrm{C}, 338 \mathrm{~T} \rightarrow \mathrm{C}, 356 \mathrm{~A} \rightarrow \mathrm{G} \\
365 \mathrm{~T} \rightarrow \mathrm{C}, 383 \mathrm{G} \rightarrow \mathrm{A}, 392 \mathrm{~T} \rightarrow \mathrm{A}\end{array}$ & 50 \\
\hline $\begin{array}{l}\text { C-terminal domain of } \\
\text { helicases }\end{array}$ & $51-400$ & 350 & 2 & $101 \mathrm{C} \rightarrow \mathrm{T}, 120 \mathrm{C} \rightarrow \mathrm{T}$ & 50 \\
\hline
\end{tabular}


Table 4. Location of genes on chromosomes of Arabidopsis and cotton.

\begin{tabular}{llll}
\hline Gene & $\begin{array}{l}\text { Location on } \\
\text { Arabidopsis }\end{array}$ & $\begin{array}{l}\text { Expected location in } \\
\text { cotton }\end{array}$ & $\begin{array}{l}\text { Location on Arabidopsis } \\
\text { chromosome }\end{array}$ \\
\hline Histone $\mathrm{H}_{2} \mathrm{~B}_{3}$ & Chr. 2 & Chr. 6 & Distal end \\
cytochrome $\mathrm{P} 450$ reductase & Chr. 4 & Chr. Not known & Near to centre \\
C-terminal domain of helicases & Chr. 1 & Chr. 5 or 9 & Distal end \\
S- adenosyl methionine synthetase & Chr. 1 & Chr. 5 or 9 & Distal end \\
Actin depolymerizing factor 2 & Chr. 3 & Chr 6 & Distal end \\
Histone $\mathrm{H}_{2} \mathrm{~B}_{1}$ & Chr. 1 & Chr. 5 or 9 & Near to centre \\
\hline
\end{tabular}

Table 5. Similarity matrix for the cotton genotypes and plant species used in study.

\begin{tabular}{|c|c|c|c|c|c|c|c|c|c|c|c|c|c|c|c|c|}
\hline & A1 & A2 & $\mathrm{C} 1$ & $\mathrm{C2}$ & D4 & D5 & D6 & D7 & D9 & G3 & E1 & $\begin{array}{c}A . \\
\text { thaliana }\end{array}$ & Populus & Papaya & Vitis & $\overline{\text { Rice }}$ \\
\hline $\mathrm{A} 1$ & 100 & & & & & & & & & & & & & & & \\
\hline A2 & 98.0 & 100 & & & & & & & & & & & & & & \\
\hline $\mathrm{C} 1$ & 77.8 & 75.7 & 100 & & & & & & & & & & & & & \\
\hline $\mathrm{C} 2$ & 75.5 & 74.0 & 92.4 & 100 & & & & & & & & & & & & \\
\hline D4 & 73.9 & 70.0 & 64.2 & 76.3 & 100 & & & & & & & & & & & \\
\hline D5 & 76.0 & 77.4 & 69.3 & 78.8 & 68.2 & 100 & & & & & & & & & & \\
\hline D6 & 71.6 & 73.3 & 80.4 & 55.4 & 72.0 & 86.9 & 100 & & & & & & & & & \\
\hline D7 & 62.1 & 64.5 & 61.8 & 65.9 & 76.3 & 75.3 & 74.9 & 100 & & & & & & & & \\
\hline D9 & 65.6 & 63.3 & 55.9 & 56.7 & 77.1 & 73.2 & 76.0 & 83.2 & 100 & & & & & & & \\
\hline G3 & 82.6 & 84.5 & 77.4 & 75.7 & 65.1 & 63.8 & 66.5 & 67.5 & 67.8 & 100 & & & & & & \\
\hline E1 & 73.3 & 76.6 & 73.9 & 72.5 & 72.0 & 68.1 & 77.1 & 69.7 & 57.1 & 66.4 & 100 & & & & & \\
\hline A. thaliana & 57.0 & 53.2 & 48.2 & 47.3 & 55.4 & 51.3 & 49.2 & 46.6 & 42.6 & 46.0 & 42.0 & 100 & & & & \\
\hline Populus & 48.1 & 51.1 & 48.8 & 44.4 & 46.2 & 47.4 & 41.4 & 42.0 & 38.4 & 39.0 & 42.5 & 36.0 & 100 & & & \\
\hline Papaya & 40.5 & 37.8 & 43.5 & 42.0 & 42.4 & 43.9 & 44.2 & 42.0 & 40.9 & 40.0 & 39.8 & 35.8 & 74.0 & 100 & & \\
\hline Vitis & 47.4 & 45.7 & 46.0 & 47.1 & 47.2 & 46.8 & 42.2 & 43.2 & 48.8 & 48.8 & 44.1 & 41.8 & 64.6 & 62.9 & 100 & \\
\hline Rice & 37.3 & 34.3 & 36.0 & 36.2 & 35.9 & 38.4 & 31.2 & 34.1 & 37.6 & 39.2 & 34.5 & 32.5 & 49.2 & 58.4 & 53.4 & 100 \\
\hline
\end{tabular}

$\left(\mathrm{A}_{1} * \mathrm{~A}_{2}\right)$. High degree of similarity was observed in $\mathrm{C}_{2} * \mathrm{C}_{1}$ (92.4\%), $\mathrm{D}_{9} * \mathrm{D}_{7}(83.2 \%)$, and $\mathrm{D}_{6} * \mathrm{D}_{5}(86.9 \%)$. On average, $\mathrm{C}$ genome has shown similarity with $\mathrm{A}_{1}$ genome $76.65 \%$ and with $\mathrm{A}_{2}$ genome $74.85 \%$. Average similarity of $\mathrm{D}$ genome with $A_{1}$ and $A_{2}$ was 69.84 and $69.7 \%$, respectively. G genome has shown $84.5 \%$ similarity with $\mathrm{A}_{2}$ genome and $82.6 \%$ similarity with $\mathrm{A}_{1}$ genome. E genome has shown $73.3 \%$ similarity with $\mathrm{A}_{1}$ and $76.6 \%$ similarity with $\mathrm{A}_{2}$ genome.

Among the sequenced genomes Arabidopsis has shown average similarity with cotton genomes $50 \%$ while Populus, Papaya, Vitis and Oryza has shown 44.5, 41.6, 46.1, and $35.9 \%$, respectively (Table 5).

Phylogenetic assessment: Phylogenetic assessment revealed two large clusters A and B. Cluster A represent diploid genomes of cotton and further comprised of three subclusters $\left(\mathrm{a}_{1}, \mathrm{a}_{2}\right.$, and $\left.\mathrm{a}_{3}\right)$. Sub cluster $\mathrm{a}_{1}$ included $\mathrm{D}$ genomes and $\mathrm{E}_{1}$ genome also joined this cluster separately. Subcluster $\mathrm{a}_{2}$ included $\mathrm{A}_{1}, \mathrm{~A}_{2}$ and $\mathrm{G}_{3}$ genomes. Subcluster $\mathrm{a}_{3}$ included $\mathrm{C}_{1}$ and $\mathrm{C}_{2}$. Arabidopsis thaliana distantly combine to this main cluster. Second cluster B include Populus,

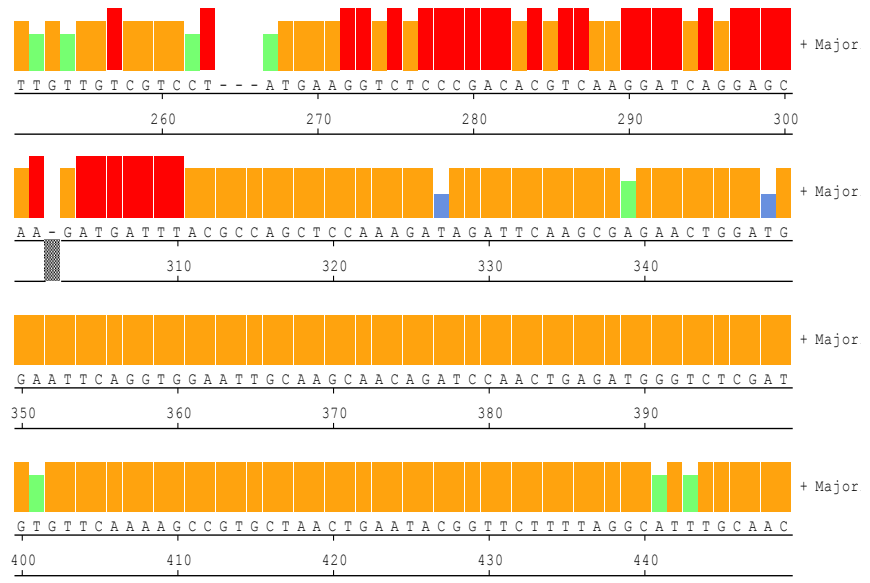

Figure 1. Alignment reports of cotton genomes and other sequenced genomes.

Similarity among sequences decrease from orange $\rightarrow$ red $\rightarrow$ green $\rightarrow$ light blue $\rightarrow$ blue. Only those SNPs were considered which were consistently present in all genomes. 


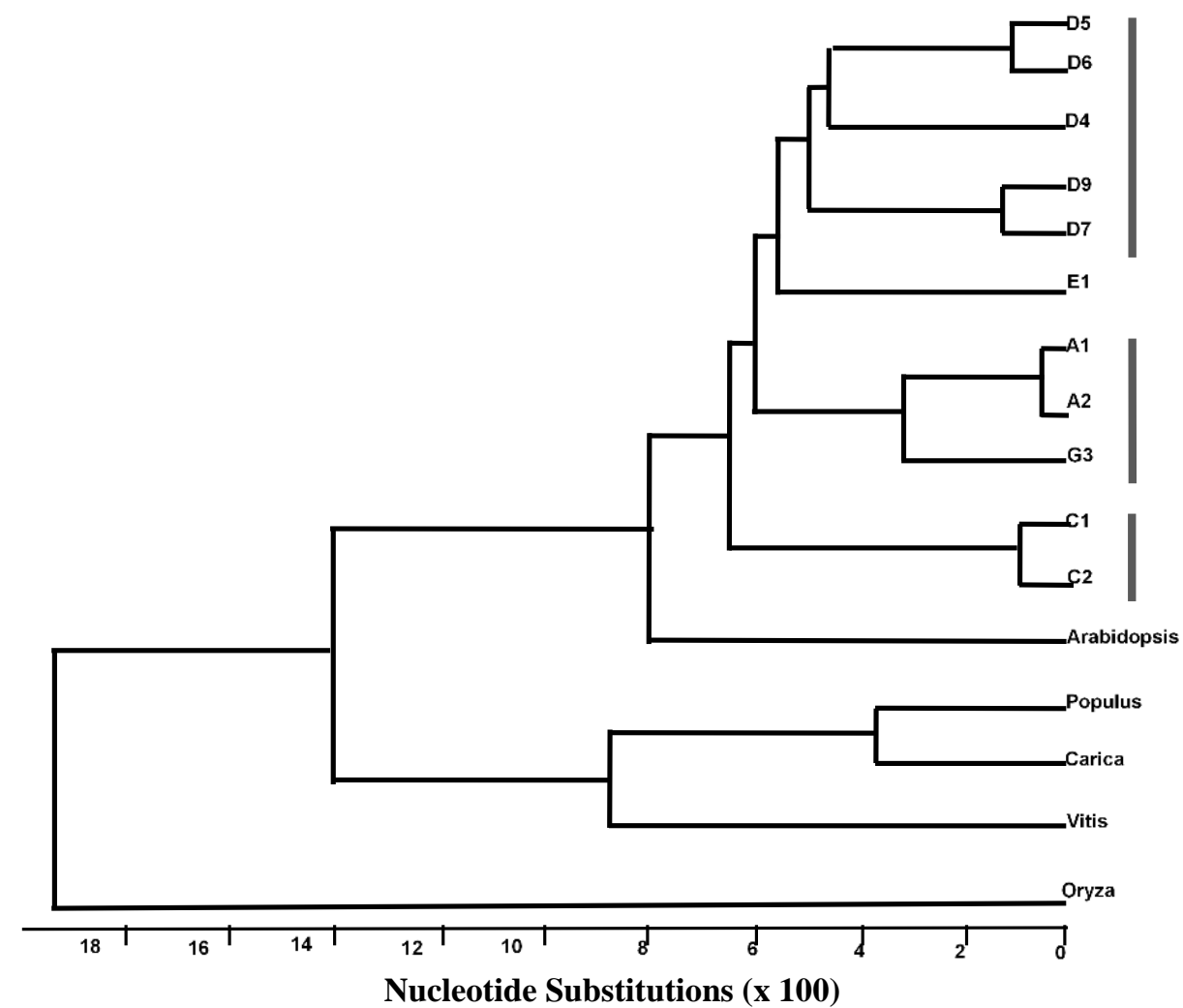

Figure 2. Phylogenetic tree of 11 diploid cotton species and five sequenced genome (Arabidopsis, Populus, Papaya, Vitis and Oryza) species on bases of SNPs studied.

Carica and Vitis while Populus and papaya are closely associated. Oryza is most distantly related with these clusters (Fig. 2).

\section{DISCUSSION}

We have harnessed SNPs for phylogenetic assessment of cotton genomes. This is an emerging technology which can facilitate the research area of evolutionary dynamics. SNPs being frequent in number can prove very authentic markers in phylogenetic studies (Batley and Edwards, 2007).

During this study of eleven diploid genome species, we observed 61 SNPs in conserved regions of seven ESTs showing homology with different genes (Table 2). Previously in a study SNPs were detected in tetraploid cotton by comparing the sequences of fiber related genes ( $\mathrm{Lu}$ et al., 2005). In another study the differential evolutionary dynamics of low copy number $A d h$ genes in tetraploid cotton by comparison of sequences of genes were explained (Small and Wendel, 2000).

When sequences of the genes obtained from cotton $(G$. arboreum) in this study were compared with sequences from other plant species to see maximum similarity (Table 2). Two sequences shown maximum similarity with $A$. thaliana, two have shown with populus, while others with Pisum sativum, Medicago truncatula, Solanum lycopersicum and Vitis vinifera. Cotton is a member of family Malvaceae and its similarity with family Brassicaeae, Salicaceae, Fabaceae, Solanaceae and Vitaceae is indicating a wide evolutionary background of cotton.

Study of number of mutation in comparison with other organisms is vital to understand rate of evolution of genes like in a study by Rausher et al. (1999). Number of SNPs observed in two genes (MT-sHSP and Actin-depolymerizing factor 2) in comparison with A. thaliana were high (101 and 103) (Fig. 1) as compared to other genes which depict a high rate of evolution in these genes (Table 3) showing different pace of evolution for different genes. Mitochondrial genes are prone to somatic mutations which are not inherited to next generation which may be cause of high mutation rates in MTsHSP (Fischel-Ghodsian et al., 2004) while high rate of mutation in Actin-depolymerizing factor 2 gene is not known. A high degree of similarity between Arabidopsis and cotton (50\%) among the outgroup species strengthen the concept given in earlier reports elucidating their origin from a common ancestor (Rong et al., 2005). Positions of these genes were identified upon comparing with the $A$. thaliana chromosomes (Table 4). While according to position on chromosomes of Arabidopsis two genes were present near to centre and four were present at distal end (Table 4). Rate of mutations does not seem to be dependent on position of gene 
on chromosome.

Nucleotide substitutions were more frequent than Indels. Indels can change the whole frame of codons translation (Liston et al., 1995; Vage and Lingaas, 2008) and are usually not tolerated in coding regions. Among substitutions $73.5 \%$ were transitions and $26.5 \%$ were transversions which is congruent with the previous studies (Wang et al., 1998; Schneider et al., 2001). For example in ten STSs, most of SNPs were of transition type $\mathrm{C} \leftrightarrow \mathrm{T}(\mathrm{A} \leftrightarrow \mathrm{G})(52.7 \%)$ in Citrus (Novelli et al., 2004). Such commonalties were found in human (66\%, Zhang and Zhao, 2004), mouse (66\%, Zhang and Zhao 2004), Drosophila (55\%, Hoskins et al., 2001), rice (61.8\%, Feltus et al., 2004) and Arabidopsis (52.8\%, Jander et al., 2002). Alterations of this type could be attributed to the actions of 5-methylcytosine deamination (Brookes, 1999; Hoskins et al., 2001; Feltus et al., 2004).

There are deep genetic backgrounds among diploid cotton germplasms for the genetic and breeding research. Within the diploid cotton species, there are many favorable characteristics such as fiber quality and yield traits, insect and pathogen resistance, tolerance to environmental stresses and so on, which may be utilized in development of superior cultivars (Abdalla et al., 2001). So an understanding of the genetic and genomic relationships of cotton species is a critical step for further utilization of extant genetic diversity and genomic information (Wu et al., 2007). Here we have utilized different genes to study relatedness of different cotton diploid species.

Tenaillon et al. (2001) suggested that the greater SNP rates can be correlated with the higher level of diversity. When comparing the different sequences among the cotton genomes we could verify that SNPs are present after every 31 bases in the cotton genomes which depict high diversity among diploid genomes of cotton at nucleotide level which is also evident with cytogenetic (Omran et al., 2007), DNA marker studies with SSRs (Guo et al., 2006; Wu et al., 2007) and also with some gene sequences (Small and Wendel, 2000).

Even though the ETSs represent a very small portion of the cotton genome, the data generated in this work were congruent with the earlier phylogenetic studies using other markers in cotton such as SSRs, RFLPs and RAPDs (Khan et al., 2000; Abdalla et al., 2001; Guo et al., 2006; Wu et al., 2007). Species representing subgenomes of the same genome were grouped in one cluster consistent with the classification of genomes (Fig. 2). A-genome species were grouped together as well as $\mathrm{C}$-genome species and D-genome species were closely associated. $\mathrm{D}_{6}$ and $\mathrm{D}_{5}$ are showing close relationship and $\mathrm{D}_{7}$ and $\mathrm{D}_{9}$ are also closely associated with them. G genome species grouped with A genome and E genome species was distantly related with other genomes which is according to the evolutionary relations of cotton genomes (Hawkins et al., 2006).

Cotton and Arabidopsis have similarities at genomic level (Rong et al., 2005) which has been elucidated in this study as well. While among the other genomes, Populus (family Salicaceae) and Papaya (family Caricaceae) are closely associated (84\%) with each other and on average $44.5 \%$ and $41.6 \%$ with cotton genomes which both belongs to woody plant families and Vitis (Vitaceae) which is a climbing herb is $64.6 \%$ and $72.9 \%$ similar with these genomes, respectively, and on average $46.1 \%$ similar with cotton genomes (Table 5). Oryza is most genetically diverged from all the genomes showing an average $38.9 \%$ similarity and $35.8 \%$ similarity with cotton genomes. This low degree of similarity of Oryza can be explained on the basis of its being a monocot species which diverged from a common ancestor 150 mya (Chaw et al., 2004). In a study a high degree of collinearity in gene order was observed in Arabidopsis, Papaya, Populus and Vitis which indicate the common ancestry of these genomes (Tang et al., 2008).

While comparing $\mathrm{A}_{1}$ genome and $\mathrm{A}_{2}$ genome with the other genomes of the genus Gossypium, $\mathrm{C}$ genome has shown more affinity with $\mathrm{A}_{1}$ genome as compared to $\mathrm{A}_{2}$ genome. While other genomes including $\mathrm{G}$ and $\mathrm{E}$ genome has shown more affinity with the $A_{2}$ genome as compared to $A_{1}$ genome. While D-genome has shown approximately equal affiliation for both the genomes which reflect a different pattern of evolution between two A genome species. Among the genomes, $\mathrm{D}_{7}$ genome has shown minimum similarity with $\mathrm{A}$ genome while $\mathrm{G}$ genome has shown maximum similarity with A-genome. These results indicate a high rate of evolution in $A_{1}$ genome as compared to $A_{2}$ genome with respect to $G$ and $\mathrm{E}$ genome while a high rate of evolution in $\mathrm{A}_{2}$ genome with respect to $\mathrm{C}$ genome species.

In conclusion SNPs are an effective tool for whole genome survey and are potent markers to survey conserved regions where other markers may not prove very effective. SNPs can be effectively utilized for phylogenetic studies as other DNA markers.

Acknowledgements: Funds for the present study were provided by Higher Education Commission (HEC) Pakistan through Presidential Young Innovator (PYI) Program and funds to $\mathrm{PhD}$ student through indigenous $\mathrm{PhD}$ program.

\section{REFERENCES}

Abdalla, A.M., O.U.K, Reddy, K.M. El-Zik and A. E. Pepper. 2001. Genetic diversity and relationships of diploid and tetraploid cottons revealed using AFLP. Theor. Appl. Genet. 102:222-229.

Aerts, J., Y. Wetzels, N. Cohen and J. Aerssens. 2002. Data mining of public SNP database for the selection of intragenic SNPs. Hum. Mutat. 20:162-173.

Ahmad, S., M. Ashraf, T. Zhang, N. Islam, T. Shaheen, M. Rahman. 2007. Identifying genetic variation in Gossypium L. based on single nucleotide polymorphism. Pak. J. Bot. 39:1245-1250. 
An, C., S. Saha, J.N. Jenkins, D.P Ma, B.E. Scheffler, R.J. Kohel, J.Z. Yu and D.M. Stelly. 2008. Cotton (Gossypium spp.) R2R3-MYB transcription factors SNP identification, phylogenomic characterization, chromosome localization, and linkage mapping. Theor. Appl. Genet. 116:1015-1026.

Araujo, A.H., M.E. Fonseca, L.S. and Boiteux. 2007. Nucleotide diversity of a major carotenoid biosynthetic pathway gene in wild and cultivated Solanum (Section Lycopersicon) species. Brazil. J. Plant. Physiol. 19:233237.

Ayeh, K.O. 2008. Expressed sequence tags (ESTs) and single nucleotide polymorphisms (SNPs): Emerging molecular marker tools for improving agronomic traits in plant biotechnology. Afr. J. Biotech. 7:331-341.

Azhaguvel, P. and T. Komatsuda. 2007. A phylogenetic analysis based on nucleotide sequence of a marker linked to the brittle rachis locus indicates a diphyletic origin of barley. Ann. Bot. 100:1009-1015.

Ball,

J. Stapley, D.A. Dawson, T.R. Birkhead, T. Burke and J . Slate. 2010. A comparison of SNPs and microsatellites as linkage mapping markers: lessons from the zebra finch (Taeniopygia guttata). BMC Genomics 11:218. doi: 10.1186/1471-2164-11218.

Bansal, V. and O. Harismendy, R. Tewhey, S.S. Murray, N.J. Schork, E.J. Topol and K.A. Frazer. 2010. Accurate detection and genotyping of SNPs utilizing population sequencing data Published in Advance. Genome Res. 20:537-545.

Batley, J. and D. Edwards. 2007. SNP applications in plants. In: N.C. Oraguzie, E.H.A. Rikkerink, S.E. Gardiner and H.N. De Silva. Published in Association Mapping in Plants; pp.95-102.

Brookes, A.J. 1999. The essence of SNPs. Gene 234:177186.

Chaw, S.M., C.C. Chang, H.L. Chen and W.H. Li. 2004. Dating the monocot-dicot divergence and the origin of core eudicots using whole chloroplast genomes. J. Mol. Evol. 58:424-441.

Chen, X., L. Levine and P.Y. Kwok. 1999. Fluorescence polarization in homogeneous nucleic acid analysis. Genome Res. 9:492-498.

Clark, R.M., G. Schweikert, S. Ossowski, G. Zeller, C. Toomajian, P. Shinn, N. Warthmann, T.T. Hu, G. Fu, D.A. Hinds, H. Chen, K.A. Frazer, D.H. Huson, B. Scholkopf, M. Nordborg, G. Ratsch, J.R Ecker and D. Weigel. 2007. Common sequence polymorphisms shaping genetic diversity in Arabidopsis thaliana. Sci. 317:338-342.

Duran, C., N. Appleby, M. Vardy, M. Imelfort, D. Edwards and J. Batley. 2009. Single nucleotide polymorphism discovery in barley using auto SNPdb. Plant Biotechnol. J. 7:326-333.

Feltus, F.A., J. Wan, S.R. Schulze, J.C. Estill, N. Jiang and A.H. Paterson. 2004. An SNP resource for rice genetics and breeding based on subspecies indica and japonica genome alignments. Genome Res. 14:1812-1819.

Fischel-Ghodsian, N., R.D. Kopke and X. Ge. 2004. Mitochondrial dysfunction in hearing loss. Mitochondrion 4:675-694.

Gamazon, E.R., W. Zhang, A. Konkashbaev, S. Duan, E.O. Kistner, D.L. Nicolae, M.E. Dolanand and N.J. Cox. 2010. SCAN: SNP and copy number annotation. Bioinformatics 26:259-262.

Guo, W., W. Wang, B. Zhou and T. Zhang. 2006. Cross species transferability of $G$. arboreum- derived ESTSSRs in the diploid species of Gossypium. Theor. Appl. Genet. 112:1573-1581.

Hawkins, J.S., H. Kim, J. Nason, R.A. Wing and J.F. Wendel. 2006. Differential lineage-specific amplification of transposable elements is responsible for genome size variation in Gossypium. Genome Res. 16:1252-1261.

Hoskins, R.A., A.C. Phan, M. Naeemuddin, F.A. Mapa, D.A. Ruddy, J.J. Ryan, L.M. Young, T. Wells, C. Kopczynski and M.C. Ellis. 2001. Single nucleotide polymorphism markers for genetic mapping in Drosophila melanogaster. Genome Res. 11:1100-1113.

Huang, C., C. Chen, S.D. Mague, J.A. Blendy and L. Liu-Chen. 2012. A common single nucleotide polymorphism $\mathrm{A} 118 \mathrm{G}$ of the $\mu$ opioid receptor alters its $\mathrm{N}$-glycosylation and protein stability. Biochem. J. 441:379-386.

Huang, W., H. Zhang, Y. Hao, X. Xu, Y. Zhai, S. Wang, Y. Li, F. Ma, Y. Li, Z. Wang, Y. Zhang, X. Zhang, R. Liang, Z. Wei, Y. Cui, Y. Li, X. Yu, H. Ji, F. He, W. Xie and G.A. Zhou. 2016. Non-synonymous single nucleotide polymorphism in the HJURP gene associated with susceptibility to hepatocellular carcinoma among Chinese. PLoS One. 11(2): e0148618. doi: 10.1371/journal.pone.0148618.

Iqbal, M.J., N. Aziz, N.A. Saeed, Y. Zafar and K.A. Mailk. 1997. Genetic diversity of some elite cotton varieties by RAPD analysis. Theor. Appl. Genet. 94:139-144.

Jander, G., S.R. Norris, S.D. Rounsley, D.F. Bus, I.M. Levin and R.L. Last. 2002. Arabidopsis map-based cloning in the postgenome era. Plant Physiol. 129:440-450.

Kanazin, V., H. Talbert, D. See, P. DeCamp, E. Nevo and D. Blake. 2002. Discovery and assay of single nucleotide polymorphism in barley (Hordeum vulgare). Plant Mol. Biol. 48:529-537.

Khan, S.A., D. Hussain,, E. Askari, J. McD Stewart, K.A. Malik and Y. Zafar. 2000. Molecular phyllogeny of Gossypium species by DNA fingerprinting. Theor. Appl. Genet. 101:931-938. 
Koornneef, M., C. Alonso-blanco and D. Vreugdenhil. 2004. Naturally occurring genetic variation in Arabidopsis thaliana. Ann. Rev. Plant. Biol. 55:141-172.

Lacape, J.M., T.B. Nguyen, B. Courtois, J.L. Belot, M. Giband, J.P. Gourlot, G. Gawryziak, S. Roquesand and B. Hau. 2005. QTL analysis of cotton fiber quality using multiple Gossypium hirsutum _ Gossypium barbadense backcross generations. Crop. Sci. 45:123-140.

Lindblad-Toh, K., E. Winchester, M.J. Daly, D.G Wang, J.N. Hirschhorn, J.P. Laviolette, K. Ardlie , D.E. Reich, E. Robinson, P. Sklar, N. Shah, D. Thomas, J.B. Fan, T. Gingeras, J. Warrington, N. Patil, T.J. Hudson and E.S Lander. 2000. Large-scale discovery and genotyping of single-nucleotide polymorphisms in the mouse. Nat. Genet. 24:381-386.

Liston, P. and D.J. Briedis. 1995. Ribosomal frameshifting during translation of measles virus $\mathrm{P}$ protein mRNA is capable of directing synthesis of a unique protein. J. Virol. 69:6742-6750.

Liu, A. and J.M. Burke. 2006. Patterns of nucleotide diversity in wild and cultivated sunflower. Genetics 173:321-330.

Lu, Y., J. Curtiss, J. Zhang, R.G. Percy and R.G. Cantrell. 2005. Discovery of single nucleotide polymorphisms in selected fiber genes in cultivated tetraploid cotton. National Cotton Council Beltwide Cotton Conference 946.

Novelli, V.M., M.A. Takita and M.A. Machado. 2004. Identification and analysis of single nucleotide polymorphisms (SNPs) in citrus. Euphytica 138:227237.

Omran, A., A. Asadollah and N. Saeid. 2007. Intragenomic diversity and geographical adaptability of diploid cotton species revealed by cytogenetic studies. Afr. J. Biotech. 6:1387-1392.

Rausher, M.D., R.E. Miller and P. Tiffin. 1999. Patterns of evolutionary rate variation among genes of the anthocyanin biosynthetic pathway. Mol. Biol. Evol. 16:266-274.

Rong, J., J.E. Bowers, S.R. Schulze, V.N. Waghmare, C.J. Rogers, G.J. Pierce, H. Zhang, J.C. Estill and A.H. Paterson. 2005. Comparative genomics of Gossypium and Arabidopsis: Unraveling the consequences of both ancient and recent polyploidy. Genome Res. 15:11981210.

Rong, J.K., C. Abbey, J.E. Bowers, C.L. Brubaker, C. Chang, P.W. Chee, T.A. Delmonte, X. Ding, J.J. Garza, B.S. Marler, C. Park, G.J. Pierce, K.M. Rainey, V. Rastogi, K. Schulze, N.L. Tronlinde, J.F. Wendel, T.A. Wilkins, R.A. Wing, R.J. Wright, X. Zhao, L. Zhu and A.H. Paterson. 2004. A 3347-locus genetic recombination map of sequence-tagged sites reveals features of genome organization, transmission and evolution of cotton (Gossypium). Genetics 166:389-417.
Schneider, K., B. Weisshaar, D.C. Borchardt and F. Salamini. 2001. SNPs frequency and allelic haplotypes structure of Beta vulgaris expressed genes. Mol. Breeding 8:63-74.

Semagn, K., A. Bjornstad and M.N. Ndjiondjop. 2006. An overview of molecular marker methods for plants. Afr. J. Biotech. 5:2540-2568.

Small, R.L. and J.F. Wendel. 2000. Phylogeny, duplication, and intraspecific variation of $A d h$ sequences in new world diploid cotton (Gossypium L., Malvaceae). Mol. Phylogenet. Evol. 16:73-84.

Tang, H., J.E. Bowers, X. Wang, R. Ming, M. Alam and A.H. Paterson. 2008. Synteny and colinearity in plant genomes. Sci. 320:486-488.

Tenaillon, M.I., M.C. Sawkins, A.D. Long, R.L. Gaut, J.F. Doebley and B.S. Gaut. 2001. Patterns of DNA sequence polymorphism along chromosome 1 of maize (Zea mays ssp. mays L.). Proc. Natl. Acad. Sci. 98:9161-9166.

Udall, J.A., J.M. Swanson, K. Haller, R.A. Rapp, M.E. Sparks, J. Hatfield, Y. Yu, Y. Wu, C. Dowd, A.B. Arpat, B.A. Sickler, T.A. Wilkins, J.Y. Guo, X.Y. Chen, J. Scheffler, E. Taliercio, R. Turley, H, McFadden, P. Payton, N. Klueva, R. Allen, D. Zhang, C. Haigler, C. Wilkerson, J. Suo , S.R. Schulze, M.L. Pierce, M. Essenberg, H. Kim, D.J. Llewellyn, E.S. Dennis, D. Kudrna, R. Wing, A.H. Paterson, C. Soderlund and J.F. Wendel. 2006. A global assembly of cotton ESTs. Genome Res. 16:441-450.

Vage, J. and F. Lingaas. 2008. Single nucleotide polymorphisms (SNPs) in coding regions of canine dopamine and serotonin-related genes. BMC Genet. 9:10. DOI: 10.1186/1471-2156-9-10.

Wang, D.G., J.B. Fan, , C.J. Siao, A. Berno, P. Young, R. Sapolsky, G. Ghandour, N. Perkins, E. Winchester, J. Spencer, L. Kruglyak, L. Stein, L. Hsie, T. Topaloglou, E. Hubbell, E. Robinson, M. Mittman, M.S. Morris, N. Shen, D. Kilburn, J. Rioux, C. Nusbaum, S. Rozen, T.J. Hudson, R. Lipshutz, M. Chee and E.S. Lander. 1998. Large-scale identification, mapping and genotyping of single-nucleotide polymorphisms in the human genome. Sci. 280:1077-1082.

Wu, Y.X., M.K. Daud, L. Chen and S.J. Zhu. 2007. Phylogenetic diversity and relationship among Gossypium germplasm using SSRs markers. Plant. Syst. Evol. 268:199-208.

Zhang, F. and Z. Zhao. 2004. The influence of neighboringnucleotide composition on single nucleotide polymorphisms (SNPs) in the mouse genome and its comparison with human SNPs. Genome 84:785-795.

Zhu, Y.L., Q.J. Song, D.L. Hyten, C.P. Van Tasell, L.K. Matukumalli, D.R. Grimm, S.M. Hyatt, E.W. Fickus, N.D. Young and P.B. Cregan. 2003. Single-nucleotide polymorphisms in soybean. Genetics 163:1123-1134. 